\title{
Yawning in neurology: a review
}

\author{
Bocejo em neurologia: uma revisão \\ Hélio A. G. Teive1, Renato P. Munhoz², Carlos Henrique F. Camargo ${ }^{3}$, Olivier Walusinski4
}

\begin{abstract}
Yawning is a stereotyped physiological behavior that can represent a sign or symptom of several conditions, such as stroke, parakinesia brachialis oscitans, parkinsonism, Parkinson's disease and epilepsy. More rarely, it can occur in patients with intracranial hypertension, brain tumor, multiple sclerosis, migraine, Chiari malformation type I, and amyotrophic lateral sclerosis. Drug-induced yawning is an uncommon clinical condition and yawning in patients with autism or schizophrenia is very rare. The aim of this review is to describe in detail the occurrence of the phenomenon in such conditions, and its' phenomenology and pathophysiology.
\end{abstract}

Keywords: yawning; parakinesia, stroke.

\section{RESUMO}

Bocejo é um comportamento estereotipado fisiológico, o qual, contudo, pode representar um sinal ou sintoma de várias condições neurológicas, tais como, acidente vascular encefálico, incluindo a parakinesia brachial oscitans, parkinsonismo, doença de Parkinson, e epilepsia. Mais raramente, o bocejo pode ocorrer em pacientes com hipertensão intra-craniana, tumor cerebral, esclerose múltipla, migrânea, malformação de Chiari tipo I, e esclerose lateral amiotrófica. Bocejo-induzido por drogas representa outra condição clínica pouco comum. De outro modo, bocejo é muito raro em pacientes com autismo e esquizofrenia. O objetivo desta revisão foi descrever em detalhes a ocorrência deste fenômeno em tais condições, sua fenomenologia e fisiopatologia.

Palavras-chave: bocejo, paracinesia, acidente vascular cerebral.

Yawning is considered an intriguing and fascinating phenomenon with an obscure etiopathogenesis. It involves opening the mouth wide and closing the eyelids while inhaling deeply and then exhaling more briefly. A yawn typically lasts $5-10$ seconds (Figure 1) 1 1,2,3,4,5,6,7 and is usually accompanied by retroflexion of the head and sometimes by elevation of the arms (known as pandiculation when occurring together). Human beings yawn with a frequency of up to 28 times a day ${ }^{1,2,3,4,5,6,7}$, often after waking up and before falling asleep. Yawning is frequently contagious and is considered a sign of boredom or even disrespectful behavior in the presence of others ${ }^{8,9,10}$. In the $19^{\text {th }}$ century, Charcot considered yawning an important clinical neurological sign, but for many years neurologists attached little importance to $\mathrm{it}^{8,11}$. Nowadays, however, although yawning continues to be a largely under-appreciated behavior, chasmology, the study of yawning, has become the focus of considerable interest ${ }^{12}$. The aim of this article is to review yawning in neurology.

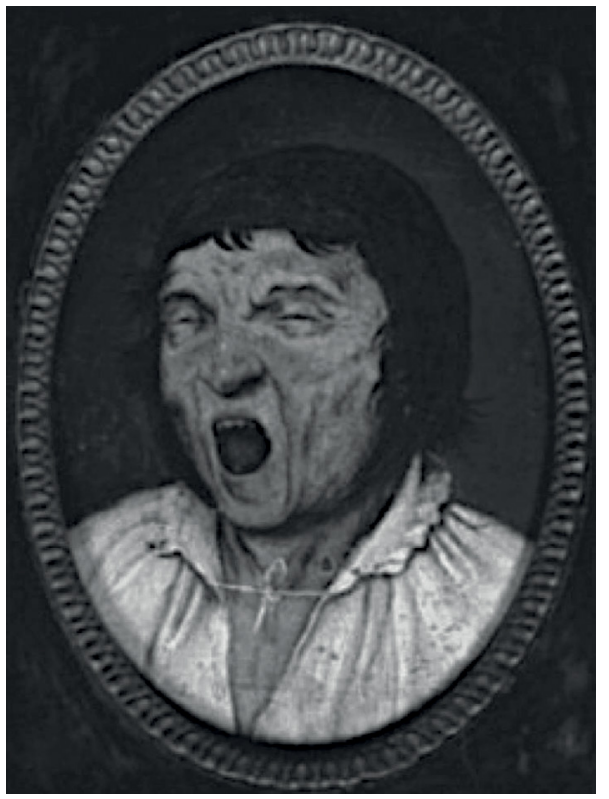

(Reproduced from Google Images: www. pinterest.com, July, 26 $6^{\text {th }}, 2016$ ). Figure 1. The Yawner. Pieter Bruegel. The Elder.

\footnotetext{
1 Universidade Federal do Paraná, Hospital de Clínicas, Departamento de Medicina Interna, Unidade de Distúrbios do Movimento, Serviço de Neurologia, Curitiba PR, Brasil;

${ }^{2}$ University Health Network, Toronto Western Hospital, Gloria and Morton Shulman Movement Disorders, Toronto, ON, Canada;

${ }^{3}$ Universidade Estadual de Ponta Grossa, Hospital Universitário, Serviço de Neurologia, Ponta Grossa PR, Brasil;

${ }^{4}$ General Practice, Brou, France.

Correspondence: Hélio Afonso Ghizoni Teive; Rua General Carneiro 1103/102,Centro; 80060-150 Curitiba PR, Brasil. E-mail: hagteive@mps.com.br Conflict of interest: There is no conflict of interest to declare.

Received 26 February 2018; Received in final form 26 March 2018; Accepted 09 April 2018.
} 


\section{METHODS}

A literature search was performed in Pubmed, for Englishlanguage articles over the time period from 1992 to 2018, using the terms "yawning" and "CNS", "neurology", "neurologic disorders". The initial references were selected using the following main exclusion criteria: 1) duplicate articles; 2) articles unrelated to the purpose of the study; 3) articles unrelated to yawning; 4) articles not including sufficient relevant data.

\section{HISTORICAL ASPECTS OF YAWNING}

Phylogenetically, yawning is a very old behavior that can be detected in most vertebrates from the fetal stages to old age ${ }^{3,4,5,8}$. Its meaning has been the subject of speculation since antiquity. In some cultures, it has been associated with Satan (Arab countries) and spirits (India), while Hippocrates associated it with apoplexy ${ }^{8}$. In the Hindu world, yawning in public is a religious offense. Since the $17^{\text {th }}$ century, various explanations for its meaning have been put forward ${ }^{8}$. Boerhaave, the founder of clinical medicine, stated in 1680, that yawns promote "the equitable distribution of spiritus in all muscles and unblock the vessels". In the $18^{\text {th }}$ century, yawning was believed to be associated with the "improvement of brain oxygenation" and, in the $19^{\text {th }}$ century, it was associated with different etiologies, including hysteria, and considered a reflex. Curiously, in 1888, in his famous Leçons du Mardi à la Salpêtrière, Charcot discussed the case of a 17-year-old patient who yawned eight times a minute, or 480 times an hour, and only stopped when she went to sleep. Her condition was believed at the time to be associated with hysteria and oxygenation of the nervous centers ${ }^{8,11}$. She had generalized epileptic seizures, complete anosmia and binasal hemianopsia. She had been amenorrheic for a year. Charcot's young patient was most likely suffering from a prolactinoma compression of her optic chiasma and her hypothalamus ${ }^{8,11}$.

During the $20^{\text {th }}$ century, substantial progress was made in understanding yawning, and several studies on this behavior and neurophysiology, hormones, dopamine receptors and social behavior were carried out ${ }^{1,2,3,4,5,6,7,7,12,13}$. Despite this progress, yawning remains a mysterious and fascinating physiological, or even pathological, phenomenon.

\section{THE NEUROPHYSIOLOGY OFYAWNING - A SUMMARY}

There are several hypotheses to explain yawning: physiological hypotheses (such as the respiratory and circulatory system, arousal, sleepiness, thermoregulatory, ear-pressure and state-change hypotheses) and the social/communication hypothesis ${ }^{4.5}$. In a study published in 2011, Guggisberg et al. $^{4}$ concluded that the hypothesis best supported by experimental evidence is the social/communication hypothesis. In contrast, Gallup 3 argued, in 2011, that the social/ communication hypothesis is unattractive and suggested that yawning is probably multifunctional across species. In their view, the most acceptable hypothesis in humans is the thermoregulatory one, according to which yawning is a brain-cooling mechanism. In 2014, Walusinski ${ }^{14}$ proposed a new hypothesis, according to which yawning switches the default-mode network to the attentional network by activating cerebrospinal fluid flow. The default-mode network is a set of interconnected brain areas identified in functional neuroimaging (fMRI) that exhibit spontaneous physiological activity during the normal resting state. There is a high level of activity in the default-mode network when the mind is not involved in specific behavioral tasks, and a low level of activity during focused attention ${ }^{14}$. According to Walusinski's hypothesis, yawning is a homeostatic process that appears when the default-mode network is active and sleepiness increases; yawning then disengages the default-mode network to promote the attentional network, which accelerates the circulation of cerebrospinal fluid, increasing clearance of somnogens such as adenosine, prostaglandin D2, VIP, prolactin and anandamide, and reducing sleepiness ${ }^{14}$. The anatomic structures involved in yawning have yet to be elucidated and, more recently, fMRI has demonstrated that different levels of the neuroaxis, including the brainstem, prefrontal cortex and subcortical regions, may be involved ${ }^{15,16}$. In 2010, Collins and Eguibar ${ }^{13}$ hypothesized that there are three main neural pathways involved in the regulation of yawning (Figure 2). Two of these are formed by groups of oxytocinergic neurons projecting from the paraventricular nucleus (one of the hypothalamic nuclei) to the hippocampus, pons, medulla and spinal cord; the other is formed by ACTH (adrenocorticotrophic hormone) and melanocyte-stimulating hormone-activated neurons projecting from the paraventricular nucleus to the hippocampus via activation of cholinergic neurons. There is also direct activation of hippocampal cholinergic neurons and a serotonergic-cholinergic pathway ${ }^{13}$. In summary, several neurotransmitters and neuropeptides, such as dopamine, acetylcholine, serotonin, glutamate, GABA, adrenergics, excitatory amino acids, nitric acid, ACTH-related peptides, $\alpha$-melanocyte-stimulating hormones and oxytocin, seem to be involved biochemically in the mechanism of yawning ${ }^{13}$. Dopamine activates oxytocin production in the paraventricular nucleus of the hypothalamus, and oxytocin in turn activates cholinergic transmission in the hippocampus and the reticular formation of the brainstem, resulting in acetylcholine induction of yawning via muscle muscarinic receptors..$^{13}$ In general, dopamine and its agonists trigger yawning, while opioid peptides and GABA reduce its frequency ${ }^{13}$. Yawning is used as an indicator of dopaminergic and oxytocinergic transmission and, in Parkinson's disease it is an expression of therapeutic dopaminergic activity, particularly as a marker of D3 dopamine receptor activity ${ }^{13,17}$. 


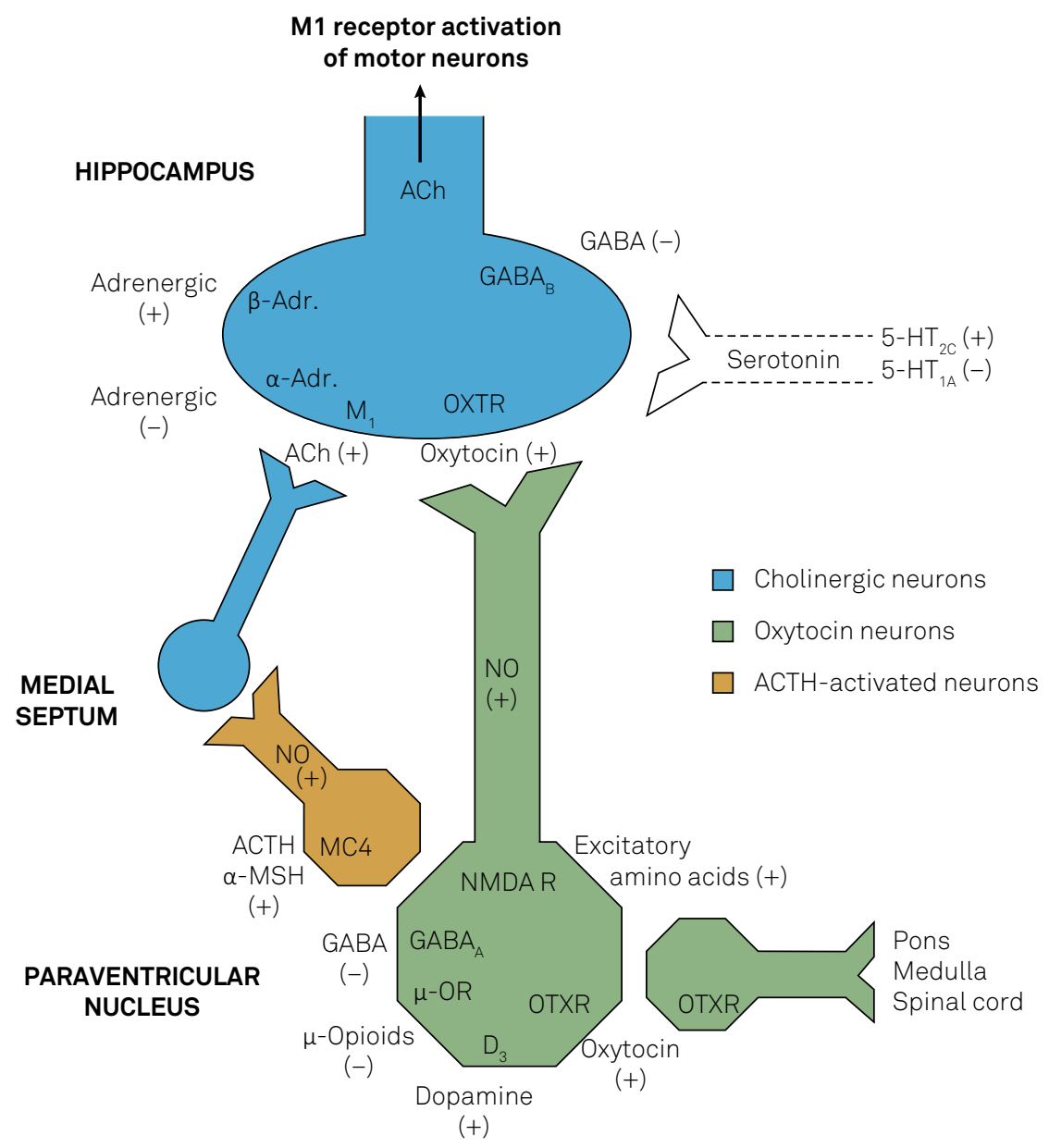

(Extracted, with permission, from Collins and Eguibar ${ }^{13)}$.

Figure 2. Yawning - Neurotransmitters.

\section{YAWNING - A CONTAGIOUS BEHAVIOR}

It is a popular belief that yawning is contagious ${ }^{10}$, and it is well known that watching another person yawn may induce the person watching to yawn too ${ }^{10,18}$. According to Guggisberg et al. ${ }^{2}$, who support the social/communication hypothesis, contagious yawning is due to activation of a complex network of brain areas associated with imitation, empathy and social behavior ${ }^{2,4}$. In 2005, Schürman et al. ${ }^{19}$ studied this intriguing phenomenon using fMRI. They observed activation of the left periamygdalar region, suggesting a connection between yawn contagiousness and amygdala activation. In contrast, Platek et al. ${ }^{20}$, using fMRI in 2005 to study contagious yawning, showed activation of the posterior cingulate and precuneus and, in 2009, Nahab et al. ${ }^{15}$, also using fMRI, demonstrated activation in the ventromedial prefrontal cortex, suggesting that mirror neuron networks play a role in yawning. Since the latter study, various papers on the relationship between contagious behavior, such as yawning and itching/scratching, and the activation of mirror neurons and the neurological mechanism of social behavior have been published ${ }^{19,20,21}$. In 2014, Provine $^{22}$ stated that contagious behaviors such as yawning have mirror-like properties.

\section{PHYSIOLOGICAL YAWNING}

Physiological yawning can occur during the transition between wakefulness and sleep or vice versa, or in response to fatigue, tiredness, stress, overwork, lack of stimulation, hunger or satiety ${ }^{1,2,3,4}$. In general, it is associated with sleep deprivation during the night and drowsiness during the day and often occurs when people are bored ${ }^{2,3,4,10,11,21}$.

\section{YAWNING IN NEUROLOGICAL CLINICAL PRACTICE}

Yawning may occur not only because of boredom, drowsiness, or by contagion but also in association with various diseases. Yawning is termed pathological, abnormal, or excessive if it is spontaneous, more frequent than generally perceived as normal, compulsive, and not triggered by appropriate stimuli including fatigue or boredom. No consensus definition exists concerning the frequency of yawns. A recent recommendation adopted the abnormal yawning frequency as three yawns per 15 minutes to decrease the likelihood that two subsequent, accidental yawns were counted as one episode with abnormal yawning ${ }^{23}$. 
Yawning can be present in the clinical picture of several neurological diseases, including stroke, multiple sclerosis, neuromyelitis optica spectrum disorders, parkinsonism, Parkinson's disease, migraine, vasovagal syncope, brain tumor, intracranial hypertension, Chiari malformation type I and epilepsy, and can be induced by drugs ${ }^{1,11}$.

\section{Yawning in sleep disorders}

In general, excessive yawning occurs more frequently in patients with sleep disorders (e.g., insomnia and sleep obstructive apnea) and is most common in children and young adults ${ }^{11}$.

\section{Excessive yawning in clinical conditions}

Other clinical conditions associated with yawning are functional digestive disorders (e.g., dyspepsia and irritable bowel syndrome), motion sickness and hypoglycemia in diabetic patients under insulin therapy ${ }^{11}$. In addition, vasovagal syncopal or presyncopal episodes frequently present with yawning as well as malaise, dizziness, visual obscuration, nausea, pallor and loss of consciousness ${ }^{11}$. Excessive yawning has also been reported in patients with depression and can be caused by the many medications used in neurology, psychiatry and internal medicine ${ }^{11}$. This issue is discussed in the following section.

\section{Drug-induced yawning}

Drug-induced yawning represents a rare and frequently not very serious adverse side-effect ${ }^{11,24}$. Antidepressants, dopaminergic agents, opioids and benzodiazepines are the main pharmacologic classes associated with yawning ${ }^{11,24}$. The most widely-used antidepressants are serotonergic agents (selective serotonin reuptake inhibitors), including fluoxetine, paroxetine, escitalopram, venlafaxine and duloxetine $^{11,24}$. Dopaminergic drugs include levodopa, dopaminergic agonists (pramipexole, ropinirole, rotigotine and apomorphine) and monoamine oxidase inhibitors ${ }^{11,24}$. Blin et al. ${ }^{25}$ evaluated eight healthy volunteers, in 1990, after they used apomorphine and after a placebo, allowing 48 hours for the medication to be washed out. They found that this dopamine agonist induced blinking and yawning in all their participants. Another interesting finding is the occurrence of yawning in the withdrawal syndrome after prolonged use of opioids or coffee ${ }^{11,24}$. In 2007, Sommet et al. ${ }^{26}$ studied druginduced yawning reported in the French Pharmacovigilance Database between 1985 and 2004. They found 28 reports involving 38 drugs, especially serotonergic agents, dopaminergic agents, opioids, and benzodiazepines ${ }^{26}$.

\section{Yawning and stroke}

Yawning has been observed secondary to acute hemorrhagic or ischemic anterior or posterior circulation stroke $^{27,28,29,30}$. In general, it indicates damage to the brainstem reticular formation and cortical and subcortical structures $^{27,29}$. In 2006, Cattaneo et al. ${ }^{29}$ published a case report of two patients with pathological yawning as a presenting symptom of brainstem ischemia involving the upper pons and the pontomesencephalic junction. Yawning has been described in patients with locked-in syndrome due to vertebrobasilar stroke caused by a thrombosed megadolichobasilar artery ${ }^{30}$. Another potential cause of yawning in patients with stroke is intracranial hypertension or even herniation ${ }^{27}$. More recently, Krestel et al. ${ }^{23}$ studied 10 patients with acute anterior circulation stroke and yawning using neuroimaging (brain MRI with diffusion-weighted images). They found a correlation between ischemic lesions in the insula and caudate nucleus and a period of abnormal yawning and suggested that the insula may be the main region of the brain responsible for serotonin-mediated yawning ${ }^{23}$. A rare and very interesting clinical condition involving yawning known as parakinesia brachialis oscitans is related to stroke and will be described below.

\section{Parakinesia brachialis oscitans}

Occasionally, in patients with acute hemiplegia, the onset of yawning is associated with an involuntary raising of the paralyzed arm ${ }^{31,32}$. This phenomenon was named parakinesia brachialis oscitans in 2005 by Walusinski et al. ${ }^{31}$, who studied four cases and compared them with other cases published in the literature over the previous 150 years. Parakinesia brachialis oscitans was probably first described by Erasmus Darwin, the grandfather of Charles Darwin, in 1794, in his book "Zoonomia of the laws of organic life" ${ }^{31}$. In their seminal paper, Walusinski et al. proposed a possible mechanism for this abnormal involuntary movement. They suggested that resection of the cortico-neocerebellar tract of the extrapyramidal system disinhibits the spino-archeocerebellar tract, enabling motor stimulation of the arm by the lateral reticular nucleus, which has a link with respiratory and locomotor rhythms. ${ }^{31}$ Several case reports have since been published describing this phenomenon, including others by Walusinski et al. and a few other reports ${ }^{32,33,34,35,36,37}$. In 2013, Zorzetto et al. ${ }^{38}$ also published a case report of parakinesia brachialis oscitans in the setting of thrombolytic therapy (Figure 3). In 2015, Kang and Dhand ${ }^{36}$ published a case report of a 63-yearold man who presented with an acute ischemic infarct in the left middle cerebral artery distribution, aphasia and paralysis of the right arm, which consistently rose to his chest when he yawned. After yawning, paralysis always resumed. In a recent publication, Alves et al. ${ }^{39}$ describe a patient who has voluntary control over that movement.

\section{Yawning, parkinsonism and Parkinson's disease}

In general, yawning is used as an indicator of activity of the dopamine-oxytocin pathway ${ }^{13}$. In patients with Parkinson's disease (PD), it is associated with the presence of dopaminergic activity ${ }^{11,13}$ and has been considered an aura for an L-dopa-induced "on" state ${ }^{17}$. It is very well known that 

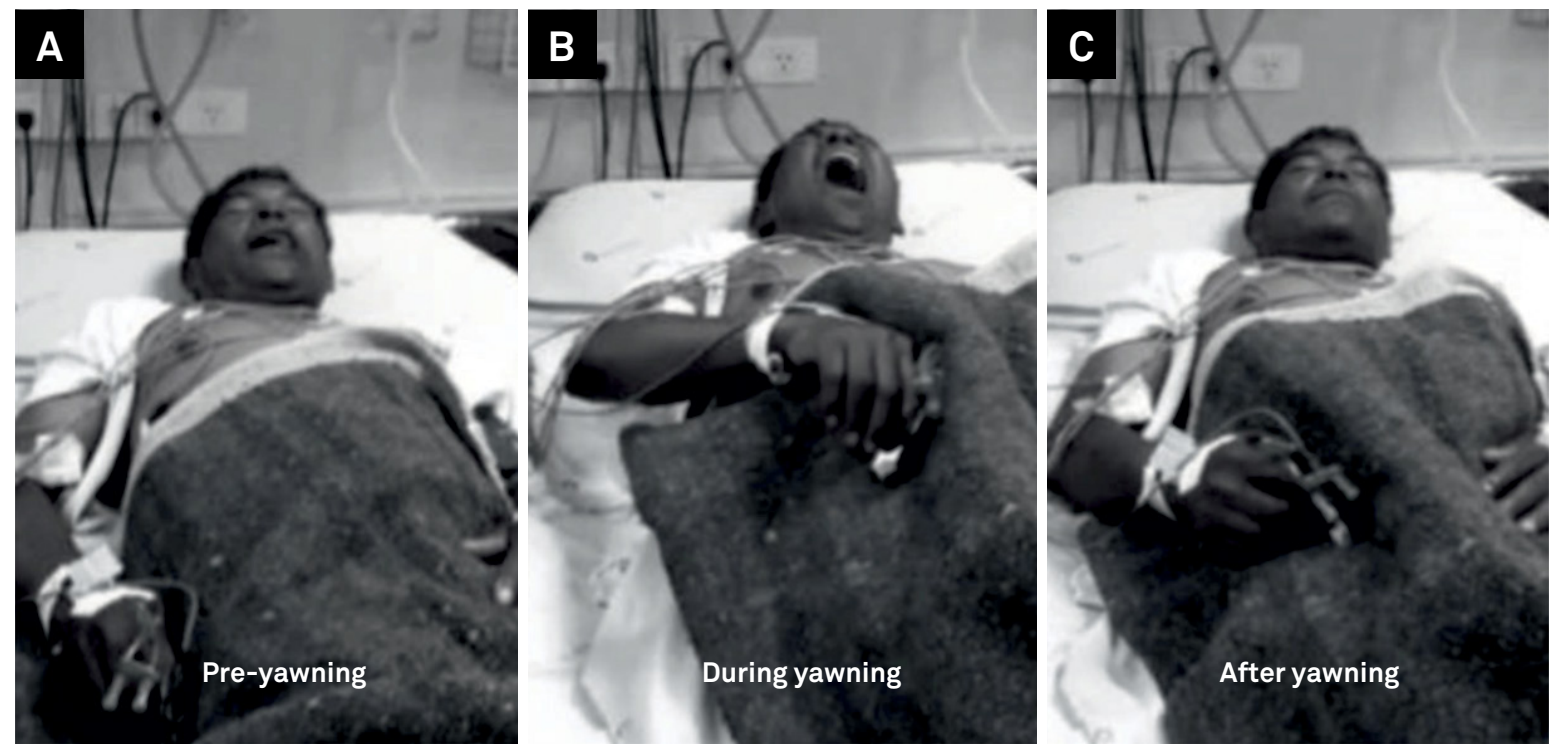

(Extracted, with permission, from Zorzetto et al. ${ }^{38}$ ).

Figure 3. Parakinesia brachialis oscitans in a patient with right hemiplegia due to ischemic stroke.

PD patients who receive apomorphine injections (a direct D1/D2 dopamine receptor agonist) frequently present with yawning before positive motor effects, sometimes in association with penile erections ${ }^{40}$. Yawning was described by von Economo in patients with acute encephalitis lethargica or postencephalitic parkinsonism ${ }^{8}$. Curiously, Sandyk et al. ${ }^{41}$ reported a series of five patients with progressive supranuclear palsy (Richardson's syndrome) who presented with balance deficits, falls, oculomotor abnormalities and bursts of repeated yawning without any correlation with their dopaminergic treatment. In 2013, Giganti et al. ${ }^{42}$ studied 18 untreated early-PD patients and compared them with 18 age-matched healthy controls. They showed that the circadian distribution of yawning was not altered in untreated patients with earlystage PD and concluded that yawning is a behavioral marker of sleepiness in de novo PD patients ${ }^{42}$.

\section{Yawning and epilepsy}

Yawning can occur in different epileptic syndromes ${ }^{11,43,44,45,46,47,48}$. It has been described in the peri-ictal period in children with infantile spasms and in patients with temporal lobe epilepsy (peri-ictal yawning preceding complex partial seizures or yawning in the post-ictal period) ${ }^{43,44,45,46,47,48}$. In 2011, Specchio et al. ${ }^{46}$ reported ictal yawning in an adult patient with drug-resistant focal epilepsy. Kuba et al. ${ }^{45}$ investigated the incidence and lateralizing value of peri-ictal yawning in patients with temporal lobe epilepsy who had undergone surgery for epilepsy. They observed peri-ictal yawning in $4.1 \%$ of 97 patients and, in $1.8 \%$ of these patients' 380 seizures, yawning occurred in the post-ictal period ${ }^{45}$. They also observed that peri-ictal yawning occurred only in patients with right-sided, nondominant temporal lobe epilepsy, suggesting that it may have a lateralizing value. ${ }^{45}$ Wasade et al. ${ }^{47}$ published an interesting case report, in 2016, of a young male who presented with controllable yawning expressed as focal seizures of frontal lobe epilepsy. In 2012, Nicotra et al. ${ }^{48}$ discussed the case of an elderly patient who presented with pathological yawning as an ictal seizure manifestation.

\section{Yawning and intracranial hypertension}

Some patients with intracranial hypertension, brain swelling or herniation due to stroke, head trauma or brain tumors may present with yawning together with headache and seizures ${ }^{11}$. In 2014, Saura et al. ${ }^{49}$ described intractable yawning associated with mature teratoma of the supramedial cerebellum. Yawning may also occur as a presenting symptom of Chiari malformation type $1^{50}$.

\section{Migraine and yawning}

Migraine represents a very common neurological problem, and the pathophysiology of migraine attacks has been shown to be related to dopaminergic transmission ${ }^{51,52}$. In the premonitory phase, yawning can be present in association with malaise, somnolence and mood changes among other manifestations ${ }^{51,52}$. Some migraineurs may experience excessive yawning during the visual aura before the attack ${ }^{51,52}$. However, excessive yawning in migraine can be improved with dopamine receptor antagonists, which are effective therapeutic agents for this condition ${ }^{51,52}$.

\section{Yawning, multiple sclerosis and neuromyelitis optica spectrum disorders}

Some patients with multiple sclerosis (MS) present with thermoregulatory dysfunction ${ }^{53}$. Therefore, sleep problems and yawning could be symptoms of $\mathrm{MS}^{11,53}$. Gallup et al..$^{54}$ also showed that yawning can provide symptom relief in MS patients. In 1996, Postert et al..$^{53}$ published a case report on pathological yawning as a symptom of MS and, in 2014, 
Lana-Peixoto et al. ${ }^{55}$ described nine patients with neuromyelitis optica spectrum disorders and excessive yawning unrelated to sleep deprivation or fatigue. They concluded that yawning may be a neglected symptom in neuromyelitis optica spectrum disorder ${ }^{55}$.

\section{Yawning and amyotrophic lateral sclerosis}

Yawning can be observed in patients with amyotrophic lateral sclerosis (ALS $)^{11}$. Williams ${ }^{56}$ published a case report, in 2000, of a 64-year-old woman who presented with progressive, very frequent yawning characterized by bouts of 20 to 30 successive yawns in association with painful cramping and a sensation of choking. During the follow-up, the patient developed bulbar palsy, and an electromyogram confirmed the diagnosis of amyotrophic lateral sclerosis ${ }^{56}$. In 2007, Wicks ${ }^{57}$ published a paper in which he noted that excessive yawning is a common sign in the bulbar-onset form of amyotrophic lateral sclerosis.

\section{Yawning, autism and schizophrenia}

Contagious yawning can be explained by the relationship between yawning and social empathy $y^{2,5,12,21,22}$. Interestingly, in some psychiatric disorders, such as autism and schizophrenia, yawning is very rare re,58,59 $^{11}$ In 2007, Senju et al. ${ }^{58}$ evaluated 24 children with autism spectrum disorder and 25 agematched, normally-developing children, in terms of their frequency of yawning, using video clips of either yawning or control mouth movements. They concluded that contagious yawning is impaired in autism spectrum disorder, supporting the idea that contagious yawning is based on the capacity for empathy $^{58}$. Haker and Rössler ${ }^{59}$, in 2009, compared changes in yawning patterns in a group of 43 schizophrenic patients and an age- and sex-matched group of healthy controls using a video with sequences of yawning, laughter and neutral faces. They observed that schizophrenic patients showed a significantly lower rate of yawning, suggesting that susceptibility to contagious yawning is reduced in patients with impaired social empathy ${ }^{59}$.

\section{Yawning - problems and solutions}

Yawning can sometimes cause complications, such as mandibular subluxation, painful cramps in the geniohyoid muscle and fracture of the styloid apophysis ${ }^{11}$. More rarely, it can trigger an attack of glossopharyngeal neuralgia, idiopathic carotidynia or even Marin Amat syndrome, a form of acquired facial synkinesis manifesting as involuntary eyelid closure on jaw opening that often occurs following the aberrant regeneration of the facial nerve after a peripheral facial palsy ${ }^{11,60}$. In contrast, yawning can improve Eustachian tube dysfunction and dysbaric facial paralysis and even acts as a therapy for vocal fatigue ${ }^{11}$. Gallup and Gallup ${ }^{5}$ studied the frequency of yawning as an initial signal of fever relief.

\section{CONCLUSION}

Yawning is a stereotyped physiological behavior that can be a sign or symptom of several neurological conditions, such as stroke (including stroke with parakinesia brachialis oscitans), parkinsonism and epilepsy. More rarely, yawning can occur in patients with intracranial hypertension, multiple sclerosis, migraine and amyotrophic lateral sclerosis and can be induced by drugs. It is rare in patients with autism spectrum disorders or schizophrenia ${ }^{11,21,24,27,31,42,53,58,59,61}$.

\section{References}

1. Walusinski O. Yawning in diseases. Eur Neurol. 2009;62(3):180-7. https://doi.org/10.1159/000228262

2. Guggisberg AG, Mathis J, Schnider A, Hess CW. Why do we yawn? Neurosci Biobehav Rev. 2010 Jul;34(8):1267-76. https://doi.org/10.1016/j.neubiorev.2010.03.008

3. Gallup AC. Why do we yawn? Primitive versus derived features. Neurosci Biobehav Rev. 2011 Jan;35(3):765-9. https://doi.org/10.1016/j.neubiorev.2010.09.009

4. Guggisberg AG, Mathis J, Schnider A, Hess CW. Why do we yawn? The importance of evidence for specific yawn-induced effects. Neurosci Biobehav Rev. 2011 Apr;35(5):1302-4. https://doi.org/10.1016/j.neubiorev.2010.12.004

5. Gallup AC, Gallup GG Jr. Yawning and thermoregulation. Physiol Behav. 2008 Sep;95(1-2):10-6. https://doi.org/10.1016/j.physbeh.2008.05.003

6. Gallup AC. A thermoregulatory behavior. Front Neurol Neurosci. 2010;28:84-9. https://doi.org/10.1159/000307084

7. Giganti F, Salzarulo P. Yawning throughout life. Front Neurol Neurosci. 2010;28:26-31. https://doi.org/10.1159/000307072

8. Walusinski O. Historical perspectives. Front Neurol Neurosci. 2010;28:1-21. https://doi.org/10.1159/000307069
9. Schiller F. Yawning? J Hist Neurosci. 2002;11(4):392-401. https://doi.org/10.1076/jhin.11.4.392.8540

10. Walusinski O. Popular knowledge and beliefs. Front Neurol Neurosci. 2010;28:22-5. https://doi.org/10.1159/000307071

11. Walusinski O. Associated diseases. Front Neurol Neurosci. 2010;28:140-55. https://doi.org/10.1159/000307098

12. Walusinski O, Deputte BL. [The phylogeny, ethology and nosology of yawning]. Rev Neurol (Paris). 2004 Nov;160(11):1011-21. French. https://doi.org/10.1016/S0035-3787(04)71138-8

13. Collins GT, Eguibar JR. Neurophamacology of yawning. Front Neurol Neurosci. 2010;28:90-106. https://doi.org/10.1159/000307085

14. Walusinski O. How yawning switches the default-mode network to the attentional network by activating the cerebrospinal fluid flow. Clin Anat. 2014 Mar;27(2):201-9. https://doi.org/10.1002/ca.22280

15. Nahab FB, Hattori N, Saad ZS, Hallett M. Contagious yawning and the frontal lobe: an fMRI study. Hum Brain Mapp. 2009 May;30(5):174451. https://doi.org/10.1002/hbm.20638

16. Nahab FB. Exploring yawning with neuroimaging. Front Neurol Neurosci. 2010;28:128-33. https://doi.org/10.1159/000307093 
17. Goren JL, Friedman JH. Yawning as an aura for an L-dopa-induced "on" in Parkinson's disease. Neurology. 1998 Mar;50(3):823. https://doi.org/10.1212/WNL.50.3.823

18. Perriol MP, Monaca C. "One person yawning sets off everyone else". J Neurol Neurosurg Psychiatry. 2006 Jan;77(1):3. https://doi.org/10.1136/jnnp.2005.078337

19. Schürmann M, Hesse MD, Stephan KE, Saarela M, Zilles K, Hari $R$ et al. Yearning to yawn: the neural basis of contagious yawning. Neuroimage. 2005 Feb;24(4):1260-4.

20. Platek SM, Mohamed FB, Gallup GG Jr. Contagious yawning and the brain. Brain Res Cogn Brain Res. 2005 May;23(2-3):448-52. https://doi.org/10.1016/j.cogbrainres.2004.11.011

21. Gupta S, Mittal S. Yawning and its physiological significance. Int J Appl Basic Med Res. 2013 Jan;3(1):11-5. https://doi.org/10.4103/2229-516X.112230

22. Provine RR. Contagious behavior: an alternative approach to mirror-like phenomena. Behav Brain Sci. 2014 Apr;37(2):216-7. https://doi.org/10.1017/S0140525X13002458

23. Krestel H, Weisstanner C, Hess CW, Bassetti CL, Nirkko A, Wiest R. Insular and caudate lesions release abnormal yawning in stroke patients. Brain Struct Funct. 2015 Mar;220(2):803-12. https://doi.org/10.1007/s00429-013-0684-6

24. Patatanian E, Williams NT. Drug-induced yawning-a review. Ann Pharmacother. 2011 Oct;45(10):1297-301. https://doi.org/10.1345/aph.1Q255

25. Blin O, Masson G, Azulay JP, Fondarai J, Serratrice G. Apomorphine-induced blinking and yawning in healthy volunteers. Br J Clin Pharmacol. 1990 Nov;30(5):769-73. https://doi.org/10.1111/j.1365-2125.1990.tb03848.x

26. Sommet A, Desplas M, Lapeyre-Mestre M, Montastruc JL; French Network of Pharmacovigilance Centers. Drug-induced yawning: a review of the French pharmacovigilance database. Drug Saf. 2007;30(4):327-31. https://doi.org/10.2165/00002018-200730040-00005

27. Renau-Lagranja J, Vilar-Ventura RM, Peinazo-Arias M. SimónGozalbo A, Claramonte B, Geffner-Sclarsky D. Yawning as a clinical sign of ischemic stroke. Rev Neurol. 2010;51:639-40.

28. Gallup AC. Abnormal yawning in stroke patients: the role of brain thermoregulation. Front Neurosci. 2014 Sep;8:300. https://doi.org/10.3389/fnins.2014.00300

29. Cattaneo L, Cucurachi L, Chierici E, Pavesi G. Pathological yawning as a presenting symptom of brain stem ischaemia in two patients. J Neurol Neurosurg Psychiatry. 2006 Jan;77(1):98-100. https://doi.org/10.1136/jnnp.2005.075267

30. Krasnianski M, Gaul C, Neudecker S, Behrmann C, Schlüter A, Winterholler M. Yawning despite trismus in a patient with locked-in syndrome caused by a thrombosed megadolichobasilar artery. Clin Neurol Neurosurg. 2003 Dec;106(1):44-6. https://doi.org/10.1016/S0303-8467(03)00045-3

31. Walusinski O, Quoirin E, Neau JP. [Parakinesia brachialis oscitans]. Rev Neurol (Paris). 2005 Feb;161(2):193-200. French. https://doi.org/10.1016/S0035-3787(05)85022-2

32. Walusinski O, Neau JP, Bogousslavsky J. Hand up! Yawn and raise your arm. Int J Stroke. 2010 Feb;5(1):21-7. https://doi.org/10.1111/j.1747-4949.2009.00394.x

33. de Lima PM, Munhoz RP, Becker N, Teive HA. Parakinesia brachialis oscitans: report of three cases. Parkinsonism Relat Disord. 2012 Feb;18(2):204-6. https://doi.org/10.1016/j.parkreldis.2011.09.020

34. Jung NY, Ahn BY, Park KH, Chung CS, Na DL, Kim EJ. A case of parakinesia brachialis oscitans. Clin Neurol Neurosurg. 2012 Feb;114(2):156-8. https://doi.org/10.1016/j.clineuro.2011.08.020

35. Meenakshisundaram R, Thirumalaikolundusubramanian P, Walusinski O, Muthusundari A, Sweni S. Associated movements in hemiplegic limbs during yawning. Front Neurol Neurosci. 2010;28:134-9. https://doi.org/10.1159/000307095

36. Kang P, Dhand A. Teaching Video Neurolmages: movement of a paralyzed arm with yawning. Neurology. 2015 Apr;84(16):e118. https://doi.org/10.1212/WNL.0000000000001489
37. Farah M, Barcellos I, Boschetti G, Munhoz RP. Parakinesia Brachialis Oscitans: A Case Report. Mov Disord Clin Pract (Hoboken). 2015;2(4):436-7. https://doi.org/10.1002/mdc3.12234

38. Zorzetto FP, Braatz VL, Walusinski O, Teive HA. Parakinesia brachialis oscitans during thrombolytic therapy. BMJ Case Rep. 2013 Feb;2013(Feb):18

39. Alves PN, Carvalho M, Reimão S, Castro J, Fonseca AC, Canhão P. Voluntary control of a plegic limb during yawning. J Neurol. 2018 Feb;265(2):433-5. https://doi.org/10.1007/s00415-017-8729-z

40. Chen JJ, Obering C. A review of intermittent subcutaneous apomorphine injections for the rescue management of motor fluctuations associated with advanced Parkinson's disease. Clin Ther. 2005 Nov;27(11):1710-24. https://doi.org/10.1016/j.clinthera.2005.11.016

41. Sandyk R. Excessive yawning and progressive supranuclear palsy. Int J Neurosci. 1987 May;34(1-2):123-4 https://doi.org/10.3109/00207458708985946

42. Giganti F, Guidi S, Ramat S, Zilli I, Raglione LM, Sorbi S et al. Yawning: a behavioural marker of sleepiness in de novo PD patients. Parkinsonism Relat Disord. 2013 Jul;19(7):703-4. https://doi.org/10.1016/j.parkreldis.2013.03.007

43. Medrano V, Selles-Galiana MF, Fernández-Izquierdo S, MalladaFrechin J, Díaz-González F, Piqueras-Rodríguez L. [Yawning and temporal lobe epilepsy]. Rev Neurol. 2005 Jul;41(1):63-4. Spanish.

44. Yankovsky AE, Andermann F, Dubeau F. Video case report post-ictal forceful yawning in a patient with nondominant hemisphere epilepsy. Med Hypotheses. 2006;67:6-14

45. Kuba R, Musilová K, Brázdil M, Rektor I. Peri-ictal yawning lateralizes the seizure onset zone to the nondominant hemisphere in patients with temporal lobe epilepsy. Epilepsy Behav. 2010 Nov;19(3):311-4. https://doi.org/10.1016/j.yebeh.2010.07.004

46. Specchio N, Carotenuto A, Trivisano M, Cappelletti S, Vigevano F, Fusco L. Ictal yawning in a patient with drug-resistant focal epilepsy: video/EEG documentation and review of literature reports. Epilepsy Behav. 2011 Nov;22(3):602-5. https://doi.org/10.1016/j.yebeh.2011.08.013

47. Wasade VS, Balki I, Bowyer SM, Gaddam S, Mohammadi-Nejad AR, Nazem-Zadeh MR et al. Controllable yawning expressed as focal seizures of frontal lobe epilepsy. Epilepsy Behav Case Rep. 2016 Aug;6:61-3. https://doi.org/10.1016/j.ebcr.2016.08.005

48. Nicotra A, Khalil NM, Owbridge P, Hakda M, Beitverda Y. Pathologica yawning as an ictal seizure manifestation in the elderly. BMJ Case Reports 2012 Oct;2012. https://doi.org/10.1136/bcr-01-2012-5618

49. Saura H, Beppu T, Matsuura H, Asahi S, Uesugi N, Sasaki M et al. Intractable yawning associated with mature teratoma of the supramedial cerebellum. J Neurosurg. 2014 Aug;121(2):387-9. https://doi.org/10.3171/2014.4.JNS132243

50. Zebian B, Hogg FR, Fu RZ, Sivakumaran R, Stapleton S. Yawning as a presenting symptom of Chiari malformation Type I: report of 2 cases. J Neurosurg Pediatr. 2015 Jun;15(6):612-4. https://doi.org/10.3171/2014.11.PEDS14139

51. Peroutka SJ. Dopamine and migraine. Neurology. 1997 Sep;49(3):650-6. https://doi.org/10.1212/WNL.49.3.650

52. Akerman S, Goadsby PJ. Dopamine and migraine: biology and clinical implications. Cephalalgia. 2007 Nov;27(11):1308-14. https://doi.org/10.1111/j.1468-2982.2007.01478.x

53. Postert T, Pöhlau D, Meves S, Nastos I, Przuntek H. Pathological yawning as a symptom of multiple sclerosis. J Neurol. 1996 Mar;243(3):300-1. https://doi.org/10.1007/BF00868532

54. Gallup AC, Gallup GG Jr, Feo C. Yawning, sleep, and symptom relief in patients with multiple sclerosis. Sleep Med. 2010 Mar;11(3):329-30. https://doi.org/10.1016/j.sleep.2009.12.007

55. Lana-Peixoto MA, Callegaro D, Talim N, Talim LE, Pereira SA, Campos GB. Pathologic yawning in neuromyelitis optica spectrum disorders. Mult Scler Relat Disord. 2014 Jul;3(4):527-32. https://doi.org/10.1016/j.msard.2014.04.002 
56. Williams DR. The yawning reflex: an upper motor neuron sign in amyotrophic lateral sclerosis. Neurology. 2000 Nov;55(10):1592-3. https://doi.org/10.1212/WNL.55.10.1592

57. Wicks P. Excessive yawning is common in the bulbar-onset form of ALS. Acta Psychiatr Scand. 2007 Jul;116(1):76. https://doi.org/10.1111/j.1600-0447.2007.01025.x

58. Senju A, Maeda M, Kikuchi Y, Hasegawa T, Tojo Y, Osanai H. Absence of contagious yawning in children with autism spectrum disorder. Biol Lett. 2007 Dec;3(6):706-8. https://doi.org/10.1098/rsbl.2007.0337
59. Hacker H, Rössler W. Empathy in schizophrenia: impaired resonance. Eur Arch Psychiatry Clin Neurosci. 2009;259(6):353-61. https://doi.org/10.1007/s00406-009-0007-3

60. Malhotra A. Marin-Amat syndrome: a case of acquired facial synkinesis. BMJ Case Rep. 2013 Jul;2013 jul18 1:bcr2013010030. https://doi.org/10.1136/bcr-2013-010030

61. Krestel H, Bassetti CL, Walusinski O. Yawning-Its anatomy, chemistry, role, and pathological considerations. Prog Neurobiol. 2018 Feb;161:61-78. https://doi.org/10.1016/j.pneurobio.2017.11.003 